\title{
Evaluation on Comprehensive Economic Competitiveness of Beijing-Tianjin-Hebei Region
}

\author{
Xiaoke Liu \\ School of Economics and Management \\ Hebei University of Science and Technology \\ Shijiazhuang, China
}

\author{
Mengqi Hou \\ School of Economics and Management \\ Hebei University of Science and Technology \\ Shijiazhuang, China
}

\begin{abstract}
Under the background of economic globalization, competition between regions gradually transforms from tangible resource competition to regional economic competitiveness which can reflect regional future development potential. The Beijing-Tianjin-Hebei integration as a major national strategy plays an important role in promoting the complementation of the "capital circle" and synergistic development. In this article the economic competitiveness evaluation index system of BeijingTianjin-Hebei region is constructed based on the concept of regional economic competitiveness. It can use the AHP to determine the Beijing-Tianjin-Hebei economic competitiveness index weight. It can help us to find out the key factors influencing the urban economic competitiveness. Then, it can use the grey comprehensive evaluation method to assess the economic competitiveness of the three areas, finding out the main disparity in Hebei province and Beijing and Tianjin region. Finally, it puts forward some targeted suggestions for the future economic construction of Hebei province.
\end{abstract}

Keywords-Beijing-Tianjin-Hebei integration; economic competitiveness; analytic hierarchy process; grey comprehensive evaluation method

\section{INTRODUCTION}

The coordinated development of Beijing-Tianjin-Hebei province became a major national strategy in 2014.It is a good way to realize the complementary advantages and mutual benefit. Hebei province, which has a lower political and economic status, plays an important role in the export of quality resources and alleviating pressure in Beijing and Tianjin. Therefore, it has always been in a weaker position than Beijing and Tianjin. In April 2017, in order to redistribute the capital function of Beijing, adjust and optimize urban layout of the Beijing-Tianjin-Hebei region, the central committee of the communist party of China, the state council decided to set up the Xiong'an New District to undertake part of the industry transfer in Beijing. It is a big opportunity for Hebei province to develop its economy.

The synergistic effect of economic integration is inseparable from the balanced development of the three regions. Hebei Province is in a weak position, so it is necessary to clarify the significant problems of its economic development. Therefore, evaluation on comprehensive economic competitiveness of Beijing-Tianjin-Hebei region is of great importance to clear the current economic competitiveness of the three areas and promote the integration of the Beijing-Tianjin-Hebei region. In addition, it can improve the planning countermeasures of Hubei province in the Beijing-Tianjin-Hebei region.

\section{EVALUATION INDEX SYSTEM OF ECONOMIC COMPETITIVENESS OF BEIJING-TIANJIN-HEBEI REGION}

\section{A. The Construction of Evaluation Index System}

It believes that regional economic competitiveness is the ability to attract high-quality resources and control and occupy the market in the process of construction and development. Internationally renowned institutions such as the Lausanne International Institute for Management Development (IMD) and the Geneva World Economic Forum (WEF) have developed an authoritative approach to assessing national competitiveness. IMD has established a multi-index comprehensive evaluation method, the determination of which is based on eight internal factors, namely, economic strength, internationalization, finance, government, infrastructure, management, science and technology, national basis. Chinese scholars have also realized the transition from a relatively poor single index evaluation (usually GDP) to a more scientific comprehensive indicator system. In addition, the index system includes indicators that reflect the economic level, economic structure and economic development support and economic development potential. This article is based on the study of domestic and overseas scholars' research on urban economic competitiveness. The economic competitiveness evaluation index system of this article includes five aspects: comprehensive economic strength, support, economic structure, international competitiveness, employment and income. 23 statistical indicators are selected to study the evaluation index system of economic competitiveness of Beijing-Tianjin-Hebei region, all of which were based on the principles of scientificity, rationality, comparability and maneuverability "Table I". 
TABLE I. ECONOMIC COMPETITIVENESS INDEX SYSTEM OF BEIJING-TIANJIN-HEBEI REGION

\begin{tabular}{|c|c|c|}
\hline Level 1 indicators index & Level 2 indicators & Level 3 indicators \\
\hline \multirow{23}{*}{$\begin{array}{l}\text { Beijing-Tianjin-Hebei } \\
\text { Economic competitiveness }\end{array}$} & \multirow{5}{*}{ Comprehensive economic strength } & C11 Regional GDP (100 million yuan) \\
\hline & & C12 Per capita GDP (yuan) \\
\hline & & C13 Total investment in fixed assets (100 million yuan) \\
\hline & & C14 General public budget revenue (100 million yuan) \\
\hline & & C15 Resident RMB savings deposit (year-end balance) \\
\hline & \multirow{6}{*}{ Supporting index } & C21 Passenger turnover (100 million people/km) \\
\hline & & C22 Freight turnover (100 million $\mathrm{t} / \mathrm{km})$ \\
\hline & & C23 Medical and health facilities (thousand beds) \\
\hline & & C24 R\&D expenditure (Ten thousand yuan) \\
\hline & & C25 Technology market turnover(Ten thousand yuan) \\
\hline & & C26 Education funding (Ten thousand yuan) \\
\hline & \multirow{4}{*}{ Economic structure index } & C31 Second industry added value (100 million yuan) \\
\hline & & C32 Third industry added value (100 million yuan) \\
\hline & & C33 The proportion of the secondary industry to GDP(\%) \\
\hline & & C34 The proportion of tertiary industry to GDP(\%) \\
\hline & \multirow{4}{*}{$\begin{array}{l}\text { international competitiveness } \\
\text { index }\end{array}$} & C41 Total export of goods (Ten thousand dollar) \\
\hline & & C42 Total import of goods (Ten thousand dollar) \\
\hline & & C43 Total foreign investment (100 million dollar) \\
\hline & & C44 International tourism foreign exchange income (Million dollar) \\
\hline & \multirow{4}{*}{ Employment and income } & $\begin{array}{l}\begin{array}{l}\text { C51 Number of registered unemployed persons in district towns(Ten } \\
\text { thousand people) }\end{array} \\
\end{array}$ \\
\hline & & C52 Average wage of employed persons in urban private sector(yuan) \\
\hline & & C53 Per capita disposable income of urban residents (yuan) \\
\hline & & C54Per capita disposable income of rural residents (yuan) \\
\hline
\end{tabular}

\section{B. Selection of Comprehensive Evaluation Method for}

Economic Competitiveness of Beijing-Tianjin-Hebei Region

The grey comprehensive evaluation method based on grey relational grade is used to compare and evaluate the evaluation objects by the correlation degree between each scheme and the optimal scheme. The steps of the grey comprehensive evaluation method are as follows:

1) Determine the comparison sequence (evaluation object) and reference sequence (evaluation criteria): Suppose the number of evaluation object is $\mathrm{m}$, the number of evaluation index is $\mathrm{n}$, the comparison sequence is:

$$
X_{i}=\left\{X_{i}(k) \mid k=1,2, \ldots, n\right\} i=1,2, \ldots, m
$$

reference sequence:

$$
\mathrm{X}_{0}=\left\{\mathrm{X}_{0}(\mathrm{k}) \mid \mathrm{k}=1,2, \ldots, \mathrm{n}\right\}
$$

2) Determine the weight of each index: Analytic hierarchy process (AHP) can be used to determine the corresponding weights of each index:

$$
\mathrm{W}=\left\{\mathrm{W}_{\mathrm{k}} \mid \mathrm{k}=1,2, \ldots, \mathrm{n}\right\}
$$
index.

$\mathrm{W}_{\mathrm{k}}$ is the corresponding weight of the Kth evaluation

3) Calculate the grey correlation coefficient

$$
\xi_{\mathrm{i}}(\mathrm{k})=\frac{\min _{i} \min _{k}\left|X_{0}(k)-X_{i}(k)\right|+\xi \max _{i} \max _{k}\left|X_{0}(k)-X_{i}(k)\right|}{\left|X_{0}(k)-X_{i}(k)\right|+\xi \max _{i} \max _{k}\left|X_{0}(k)-X_{i}(k)\right|}
$$

4) Calculate the gray weighted correlation degree and establish the gray correlation degree

The calculation formula of grey weighted correlation degree is: $r_{i}=\sum_{k=1}^{n} W_{k} \xi_{i}(k)$

$r_{i}$ is the grey weighted correlation degree of the with object to the ideal object.

5) Evaluation analysis: According to the grey weighted correlation degree, each evaluation object can be sorted, and the association order of evaluation objects can be established. The greater the correlation degree is, the better the evaluation result is.

\section{COMPREHENSIVE EVALUATION AND ANALYSIS OF ECONOMIC COMPETITIVENESS OF BEIJING, TIANJIN AND HEBEI}

\section{A. Grey Comprehensive Evaluation Process of Economic Competitiveness}

1) Determine the comparison sequence and reference sequence: Firstly, it could select the reference sequence in "Table II". 
TABLE II. COMPARISON SEQUENCE AND REFERENCE SEQUENCE

\begin{tabular}{|c|c|c|c|c|c|c|}
\hline Level 1 indicators index & Level 2 indicators & Level 3 indicators & Beijing & Tianjin & Hebei & reference sequence \\
\hline \multirow{23}{*}{$\begin{array}{l}\text { Beijing-Tianjin-Hebei } \\
\text { Economic competitiveness }\end{array}$} & \multirow{5}{*}{$\begin{array}{l}\text { Comprehensive } \\
\text { economic strength }\end{array}$} & C11 & 21330.83 & 15726.93 & 29421.15 & 29421.15 \\
\hline & & C12 & 99995 & 105231 & 39984 & 105231 \\
\hline & & $\mathrm{C} 13$ & 6924.2 & 10518.2 & 26671.9 & 26671.9 \\
\hline & & C14 & 4027.16 & 2390.35 & 2446.62 & 4027.16 \\
\hline & & C15 & 24158.4 & 7916.9 & 25690.1 & 25690.1 \\
\hline & \multirow{6}{*}{ Supporting index } & $\mathrm{C} 21$ & 273.93 & 246.74 & 1276.66 & 1276.66 \\
\hline & & $\mathrm{C} 22$ & 1036.71 & 3602.38 & 12684.47 & 12684.47 \\
\hline & & $\mathrm{C} 23$ & 10.98 & 6.09 & 32.29 & 32.29 \\
\hline & & $\mathrm{C} 24$ & 2335010 & 3228057 & 2606711 & 3228057 \\
\hline & & $\mathrm{C} 25$ & 31371854 & 3885631 & 292228 & 31371854 \\
\hline & & $\mathrm{C} 26$ & 9998366 & 5699615 & 10298143 & 10298143 \\
\hline & \multirow{4}{*}{$\begin{array}{l}\text { Economic } \\
\text { index }\end{array}$} & $\mathrm{C} 31$ & 4544.8 & 7731.85 & 15012.85 & 4544.8 \\
\hline & & $\mathrm{C} 32$ & 16627.04 & 7795.18 & 10960.84 & 16627.04 \\
\hline & & $\mathrm{C} 33$ & 21.3 & 49.2 & 51 & 21.3 \\
\hline & & C34 & 77.9 & 49.6 & 37.3 & 77.9 \\
\hline & \multirow{4}{*}{$\begin{array}{l}\text { international } \\
\text { competitiveness } \\
\text { index }\end{array}$} & C41 & 6233842 & 5259066 & 3571020 & 6233842 \\
\hline & & C42 & 35318018 & 8129542 & 2416716 & 2416716 \\
\hline & & C43 & 2010 & 1441 & 621 & 2010 \\
\hline & & C44 & 4608 & 2992.1 & 534.19 & 4608 \\
\hline & \multirow{4}{*}{$\begin{array}{l}\text { Employment } \\
\text { income }\end{array}$} & C51 & 7.4 & 22.5 & 38.3 & 7.4 \\
\hline & & $\mathrm{C} 52$ & 52902 & 47838 & 31459 & 52902 \\
\hline & & C53 & 48531.8 & 31506 & 24141 & 48531.8 \\
\hline & & \begin{tabular}{|l} 
C54 \\
\end{tabular} & 18867.3 & 17014.2 & 10186.1 & 18867.3 \\
\hline
\end{tabular}

a. Data source: National Statistics Yearbook 2015.

2) Index normalization processing

$$
X_{i k}=\frac{V_{i k}-\min _{i} V_{i k}}{\max _{i} V_{i k-\min _{i} V_{i k}}}
$$

TABLE III. INDEX VALUES AFTER STANDARDIZED PROCESSING

\begin{tabular}{|c|c|c|c|c|c|c|}
\hline \multirow{5}{*}{\begin{tabular}{l}
\multicolumn{1}{c}{ Level 1 index } \\
Beijing-Tianjin- \\
Hebei \\
Economic \\
competitiveness
\end{tabular}} & \multirow{6}{*}{$\begin{array}{c}\text { Level } 2 \text { index } \\
\text { Comprehensive economic strength }\end{array}$} & Level 3 index & \multicolumn{3}{|c|}{ Comparison sequence normalization } & \multirow{2}{*}{$\begin{array}{l}\text { Normalized reference sequence } \\
1\end{array}$} \\
\hline & & C11 & 0.4092 & 0 & 1 & \\
\hline & & $\mathrm{C} 12$ & 0.9197 & 1 & 0 & 1 \\
\hline & & C13 & 0 & 0.1819 & 1 & 1 \\
\hline & & C14 & 1 & 0 & 0.0343 & 1 \\
\hline & & C15 & 0.9138 & 0 & 1 & 1 \\
\hline & Supporting index & $\mathrm{C} 21$ & 0.0260 & 0 & 1 & 1 \\
\hline & & $\mathrm{C} 22$ & 0 & 0.2202 & 1 & 1 \\
\hline & & $\mathrm{C} 23$ & 0.1866 & 0 & 1 & 1 \\
\hline & & $\mathrm{C} 24$ & 0 & 1 & 0.3042 & 1 \\
\hline & & $\mathrm{C} 25$ & 1 & 0.1156 & 0 & 1 \\
\hline & & $\mathrm{C} 26$ & 0.9348 & 0 & 1 & 1 \\
\hline & Economic structure index & $\mathrm{C} 31$ & 0 & 0.3044 & 1 & 0 \\
\hline & & $\mathrm{C} 32$ & 1 & 0 & 0.3584 & 1 \\
\hline & & $\mathrm{C} 33$ & 0 & 0.9393 & 1 & 0 \\
\hline & & $\mathrm{C} 34$ & 1 & 0.3029 & 0 & 1 \\
\hline & International competitiveness index & $\mathrm{C} 41$ & 1 & 0.6339 & 0 & 1 \\
\hline Level 1 index & Level 2 index & Level 3 index & \multicolumn{3}{|c|}{ Comparison sequence normalization } & Normalized reference sequence \\
\hline \multirow{7}{*}{$\begin{array}{l}\text { Beijing-Tianjin- } \\
\text { Hebei } \\
\text { Economic } \\
\text { competitiveness }\end{array}$} & \multirow[t]{3}{*}{ International competitiveness index } & $\mathrm{C} 42$ & 1 & 0.1736 & 0 & 0 \\
\hline & & $\mathrm{C} 43$ & 1 & 0.5903 & 0 & 1 \\
\hline & & $\mathrm{C} 44$ & 1 & 0.6033 & 0 & 1 \\
\hline & \multirow[t]{4}{*}{ Employment and income } & C51 & 0 & 0.4886 & 1 & 0 \\
\hline & & C52 & 1 & 0.7638 & 0 & 1 \\
\hline & & $\mathrm{C} 53$ & 1 & 0.3019 & 0 & 1 \\
\hline & & C54 & 1 & 0.7865 & 0 & 1 \\
\hline
\end{tabular}


3) Determine the corresponding weight of each index value: We use analytic hierarchy process (AHP) to determine the weight. AHP is a multi-criterion decision method combining qualitative and quantitative analysis. Firstly, construct judgment matrix on the basis of index system. The judgment matrix is constructed by consulting many experts. Then test the judgment matrix for consistency, determine the single sorting and the total sorting. The results are shown in the "Table IV".

Enter the relevant data into the computer software and calculate the gray correlation coefficient and the gray weighted correlation degree, the results are as follows:

TABLE IV. GRAY CORRELATION DEGREE CALCUlation RESUlt

\begin{tabular}{|l|l|l|l|l|}
\hline Index & Final weight & \multicolumn{1}{|c|}{ Beijing } & \multicolumn{1}{|c|}{ Tianjin } & Hebei \\
\hline C11 & 0.1261 & 0.4583 & 0.3333 & 1 \\
\hline C12 & 0.2567 & 0.8616 & 1 & 0.3333 \\
\hline C13 & 0.0532 & 0.3333 & 0.3793 & 1 \\
\hline C14 & 0.0532 & 1 & 0.3333 & 0.3411 \\
\hline C15 & 0.0232 & 0.8529 & 0.3333 & 1 \\
\hline C21 & 0.0055 & 0.3393 & 0.3333 & 1 \\
\hline C22 & 0.0055 & 0.3333 & 0.3907 & 1 \\
\hline C23 & 0.0013 & 0.3807 & 0.3333 & 1 \\
\hline C24 & 0.0025 & 0.3333 & 1 & 0.4181 \\
\hline C25 & 0.0132 & 1 & 0.3611 & 0.3333 \\
\hline C26 & 0.0132 & 0.8846 & 0.3333 & 1 \\
\hline C31 & 0.0155 & 1 & 0.6215 & 0.3333 \\
\hline C32 & 0.0318 & 1 & 0.3333 & 0.4379 \\
\hline C33 & 0.0712 & 1 & 0.3473 & 0.3333 \\
\hline C34 & 0.1466 & 1 & 0.4176 & 0.3333 \\
\hline C41 & 0.0289 & 1 & 0.5773 & 0.3333 \\
\hline C42 & 0.0028 & 0.3333 & 0.7422 & 1 \\
\hline C43 & 0.0135 & 1 & 0.5496 & 0.3333 \\
\hline C44 & 0.0060 & 1 & 0.5576 & 0.3333 \\
\hline C51 & 0.0072 & 1 & 0.5057 & 0.3333 \\
\hline C52 & 0.0734 & 1 & 0.6791 & 0.3333 \\
\hline C53 & 0.0153 & 1 & 0.4173 & 0.3333 \\
\hline C54 & 0.0343 & 1 & 0.7008 & 0.3333 \\
\hline 4 & & & & \\
\hline
\end{tabular}

4) Gray comprehensive evaluation results

TABLE V. GRAY COMPREHENSIVE EVALUATION RESULTS OF ECONOMIC COMPETITIVENESS OF BEIJING, TIANJIN AND HEBEI

\begin{tabular}{|l|l|l|}
\hline \multicolumn{1}{|c|}{ Province } & \multicolumn{1}{c|}{ Correlation } & \multicolumn{1}{c|}{ Ranking } \\
\hline Beijing & 0.84415990 & 1 \\
\hline Tianjin & 0.580020747 & 2 \\
\hline Hebei & 0.491115872 & 3 \\
\hline
\end{tabular}

Gray comprehensive evaluation results show that the weighted grey correlation of Beijing is 0.8442, ranking first; the weighted grey correlation of Tianjin is 0.5800 , ranking second; the weighted grey correlation of Hebei is 0.4911 , ranking third. As can be seen from the evaluation process and evaluation results, compared with Beijing and Tianjin, the economic competitiveness of Hebei is weak in many ways. Through the result of the grey comprehensive evaluation, we can find out the disparity between each city, and then find out what can be done to improve their economic and economic competitiveness. The following is a detailed analysis of the five first-level indexes in "Table V".

\section{B. Analysis of Comprehensive Evaluation Results of Economic Competitiveness}

1) Analysis of the results of comprehensive economic strength: From the point of view of economic competitiveness index weight, the weight of comprehensive economic strength is 0.5123 , which shows that the contribution rate of the economic strength of city is very big. Because of the population in Hebei province is greater than the Beijing-Tianjin region, so reference significance of total index is not big. From the more representative relative levels of "per capita GDP" index, the grey correlation degree of Hebei is only 0.33 , ranking in the bottom of the three cities. This is consistent with the statistics shown in the statistical yearbook. Beijing and Tianjin have an average per capita GDP of around one hundred thousand, while the per capita GDP of Hebei is less than forty thousand yuan.

2) Analysis of support indicators: The "science and technology market turnover" and "education funds" two secondary index of supportive contribution rate is as high as $32 \%$, a powerful interpretation of science and technology and education in the important position in the economic construction. The Grey relational degree of "technology market turnover" in Beijing is 1, Tianjin is 0.3612 and Hebei is 0.3333 . Through relevant data analysis, Beijing's per capita technology market turnover is about 15,000, while Hebei province is only 40 yuan. Therefore, Tianjin and Hebei province have to increase their investment in science and technology in order to improve their economic competitiveness, so as to promote regional economic development through scientific and technological progress.

3) Analysis of economic structure indicators: The index of economic structure, which accounts for 0.265 of the weight of economic competitiveness index system, is the most important index of economic competitiveness after comprehensive economic strength index. Therefore, economic structure is an important factor affecting regional economic growth, which determines the basic mode of regional resource allocation. Under the economic structure index of four secondary indexes, Beijing all of Grey correlation degree is 1 (i.e. all of the reference sequence), Tianjin "tertiary industry accounted for the index of the Grey correlation degree is 0.4177 , Hebei is 0.3333 . According to relevant data, Beijing's tertiary industry accounts for 77.9 percent of GDP, while the second industry in Hebei province accounts for a large proportion of GDP. The development degree of the tertiary industry has become the main symbol to measure the development degree of modern economy, so the industry of Beijing is mature. Hebei province should accelerate the development of the tertiary industry and realize the rationalization of the industrial structure.

4) Analysis of international competitiveness results: Under the index of international competitiveness, Beijing is in "total exports of goods" "international tourist foreign exchange income", "foreign investment" Grey correlation 
degree of the three indicators are 1, Tianjin "exports of goods" index of the Grey correlation degree is 0.5773 , the international tourism foreign exchange earnings, "the Grey correlation degree is 0.5576 , the total amount of foreign investment" Grey correlation degree is 0.5497 , both in the medium level. In Hebei province, the Grey relational degree of the other three indexes is 0.3333 . It can be seen that Beijing is the most "connected with internationalization", with Tianjin second and Hebei the lowest.

5) Analysis of employment and income results: The index system of employment and income is one of the four secondary indexes of the evaluation index system of economic competitiveness. Among the four secondary indexes, the Grey correlation degree of Beijing is 1, ranking first. In Hebei province, the Grey correlation was 0.3333, ranking third. It can be said that this result is in line with our knowledge that Beijing's employment and income is significantly higher than that of Hebei. Tianjin is a little stronger than Hebei, but it still has a certain gap with Beijing.

\section{The PRominent PRoblems Faced by HebeI IN THE INTEGRATION OF BEIJING-TIANJIN-HEBEI REGION}

\section{A. The Level of Scientific and Technological Innovation Is Low}

In 2015, the total volume of science and technology market turnover in Hebei province was less than one-tenth of the total volume of the Beijing technology market, and the difference in the per capita technology market turnover was even more bizarre. The main reason is that Hebei province has limited scientific and technological resources, weak scientific and technological capabilities, and lack of scientific and technological innovation ability. Although education expenditure in Hebei province is the largest in three places, the Beijing-Tianjin region has a large number of better education resources.

\section{B. Unreasonable Industrial Structure}

The second industry in Hebei province is the highest in Beijing and Tianjin, while the third industry is the lowest. And its mainstay industries are mostly energy-intensive, highly polluting industries such as steel, cement and glass. Industrial technology and insufficient innovation is low. Second, the Beijing and Tianjin region, with its outstanding advantages in the tertiary industry, has grabbed a lot of resources, which has caused the development of the tertiary industry in Hebei province to be impeding.

\section{Internationalization Level Is Low}

Economic globalization has brought unprecedented opportunities to China's economic development. However, from the definition of regional economic competitiveness and the result of Grey evaluation, its appeal to high quality resources and its ability to occupy and control international markets are not satisfactory. Relevant data show that the total amount of foreign investment attracted to Hebei province is less than that of Beijing, and the foreign exchange income of international tourism is less than $1 / 10$. In the development of economic integration, Hebei province should follow the new trend of "bringing in" and "going out" in the country, unleash economic vitality and steadily improve its economic competitiveness.

\section{Employment and Income Aren't Optimistic}

Another significant problem in Hebei province's economic integration development is "high unemployment, low average wages and low disposable income". Employment problem is not only an economic problem, but also a political question, to solve this problem is bad, will not only hinder the healthy development of the economy in Hebei province, and even directly related to China's socialist modernization process, related to social stability.

\section{Countermeasures of Hebei Province IN THE INTEGRATION OF BEIJING, TIANJIN AND HEBEI}

\section{A. Increase Efforts to Support Innovation}

Science and technology are the main driving force of economic and social, playing a more and more important role in the economic development of the city. If we want to improve the economic competitiveness of Hebei, we must increase investment in science and technology, encourage scientific and technological innovation, and promote regional economic development with scientific and technological progress. Education is a social activity to train talents suitable for economic development, which is closely related to economic development and social progress. Therefore, Specific measures can be taken into consideration:

- Formulate the corresponding policy support, promote the combination of production and research.

- Insist on using informationization to promote industrialization, widely used high-tech transformation, upgrading the manufacturing industry.

It should form more brands with independent intellectual property rights, give full play to the important supporting role of manufacturing industry in economic development.

\section{B. Countermeasures to Optimize the Industrial Structure}

Hebei in Beijing, Tianjin and integration in one of the functional positioning is "industrial transformation and upgrading test area". The establishment of Xiongan district is the important measure to undertake capital function counseling in our province, Beijing production industry and scientific research to the industrial transfer in Hebei Province, this measure can not only improve the technology content of our province can industry industrial structure in our province brought by the transformation of scientific research and a lot of technical talent. We should seize this major opportunity, promote the optimization and upgrading of the second industry, and vigorously develop new industries and third industries. Specific measures can be taken into consideration:

- Shut down or integrate polluting enterprises, eliminating backward production capacity, developing new energy sources, optimizing and 
upgrading production technology, and developing energy-saving and environmental protection alternatives.

- Keep pace with the times and realize the integration of industrialization and informatization

- Reduce the threshold of the new industry and give the necessary policy and financial support

- Actively guide the development of new industries and third industries, introduce good projects and carry out pilot work, and attach importance to the construction of new industrial bases, so as to create a favorable environment for development.

\section{Countermeasures to Improve the Internationalization Level}

Transportation is the basis of trade and investment. The developed transportation system is the key to enhance the import and export volume and attract foreign investment. Hebei province should seize the coordinated development of economy in the transportation integration policy to do the following:

- Use the geographical advantages, vigorously promote the high-speed rail, airport and port construction, establish and improve the "Dredging the interior and exterior" provincial, interregional and international transport channel.

- Establish the Beijing-Tianjin-Hebei integrated transportation management mechanism, strengthen the policy of the three places, and the connection between the regulations and the system.

- Establish an information exchange platform to accurately and accurately reflect the problems existing in the process of the construction of the three-way transport integration, and actively apply for more favorable policies.

- Combine the characteristics of small and mediumsized cities and use the opportunity of integration of Beijing-Tianjin-Hebei to win more policy support.

Cultural cities such as Qinhuangdao, Chengde should actively respond to national construction "global tourism demonstration area", making tourism industry into strategic pillar industry in our province; Tangshan, Cangzhou and other coastal cities should strengthen the construction of transportation industry.

\section{Measures to Improve Employment and Income}

The establishment of the Xiong'an New District will bring a great deal of employment opportunities to our province. One of the important reasons for the low employment rate in Hebei and the influx of talents into Beijing and Tianjin is that our province lacks sufficient attraction for the labor force. Therefore, we can proceed from the following aspects: 1) Increase investment in infrastructure projects in our province, pay attention to medical, social security, education and other livelihood issues. 2) Formulate talent support policies to attract and retain talent. 3) Establish long-term mechanism of urban residents' income, improve the enterprise wage guidelines and minimum wage system, and actively expand employment channels, increase farmers' income. 4) Establish and improve the income distribution adjustment mechanism, and strive to alleviate the widening trend of the income distribution gap among some members of society. We will encourage social forces to participate in the welfare work, encourage social organizations and individuals to help the poor in poverty alleviation, improve the ability of social assistance, and promote the socialization of social welfare services.

\section{CONCLUSION}

The deepening integration of Jing-Jin-Ji has brought great opportunities and challenges to the development of Hebei province. The important strategy of establishing the new area of the new district is to bring the "transportation integration" and "industrial upgrading" to the climax. The research on the evaluation system of regional economic competitiveness can provide important basis for regional discovery and formulation of development strategy. Based on the analytic hierarchy process (AHP) and Grey comprehensive evaluation method to find out the Hebei province in the outstanding problems existing in the integration of the Beijing-Tianjin-Hebei region:

- the low level of science and technology innovation

- the unreasonable industry structure

- the low level of internationalization

- the employment and income is not optimistic

Aiming at the outstanding problems in Hebei province that exist in the development of integration of the BeijingTianjin-Hebei region, we combine with the current form and development of the integration of the Beijing-Tianjin-Hebei region planning and presents the corresponding countermeasures, in order to promote the future development of economic construction in Hebei province.

\section{REFERENCES}

[1] Cui Dongchu, Song Zhijie,The problems and countermeasures existed in the regional economic integration of the Beijing-Tianjin-Hebei region [J]. Economic aspect, 2012.5.

[2] Mao Xinya, Li Yi. Theory and practice of regional coordinated development [M]. Beijing: people's publishing house, 2010.

[3] Zheng Hong. Study on regional differences and economic integration in Beijing-Tianjin-Hebei region [D]. Beijing: north China electric power university degree thesis, 2012.

[4] Wang Wei, Comprehensive evaluation of economic competitiveness in Hebei province [D], Hebei university of science and technology, October 2009.

[5] Feng Yiping, Evaluation study on comprehensive competitiveness of county economy in Xinxiang city, Henan province [D], Jiangsu university, May 2010.

[6] Zhang Hongzhou, Regional economic competitiveness evaluation index system and its method selection [J], Journal of Shanghai institute of applied technology, March 2010. 
[7] Jia Jingli, Sun Wensheng, Comprehensive evaluation study on economic competitiveness of county in Hebei province [J], Tianjin agricultural science, 2011.17 (1) : 144-148.

[8] Xu Chenghong, The comparison and evaluation of economic competitiveness in the western Middle East region [J], the rise of the central bank BBS, August 2007.

[9] Peng Zhanglin, Zhang Qiang, Yang Shanlin, Comprehensive evaluation theory and method research review [J], China management science, November 2015.

[10] Wang Hui, Wang Fengyun, Comparison of regional economic competitiveness of henan province and development countermeasures [J], China youth technology, 167. 